\title{
PENGARUH LEVERAGE FINANCIAL DAN KEBIJAKAN DIVIDEN TERHADAP NILAI PERUSAHAAN (STUDI PADA PERUSAHAAN MANUFAKTUR DI BURSA EFEK INDONESIA)
}

\author{
Abdul Wahab \\ Politeknik Informatika Nasional Makassar \\ (Wahabpolinas@gmail.com)
}

\begin{abstract}
This study aims to examine and analyze the effect of partially or simultaneously financial leverage and dividend policy on firm value in manufacturing companies on the Indonesian stock exchange. Data collection uses secondary data using purposive sampling technique. The population in this study is the automotive sub-sector manufacturing companies and components listed on the Indonesia stock exchange during the 2014-2016 period of 15 companies, while the samples taken were the number of observations for 3 years (2014-2016) with the number of companies observing 12 obtained were analyzed using multiple linear regression analysis. The results show that all hypotheses have a significant effect based on the $t$ test and $F$ test. This means that both partially and simultaneously financial leverage and dividend policy have a significant effect on firm value in manufacturing companies on the Indonesian stock exchange.
\end{abstract}

Keywords: Financial Leverage, Dividend Policy, Company Value.

\begin{abstract}
ABSTRAK
Penelitian ini bertujuan untuk menguji dan menganalisis pengaruh secara parsial maupun simultan leverage financial dan kebijakan dividen terhadap nilai perusahaan pada perusahaan manufaktur di bursa efek Indonesia. Pengumpulan data menggunakan data sekunder dengan menggunakan teknik purposive sampling. Populasi dalam penelitian ini adalah perusahaan manufaktur sub sektor otomotif dan komponen yang terdaftar di bursa efek Indonesia selama periode 2014-2016 sejumlah 15 perusahaan, sedangkan sampel yang diambil jumlah pengamatan selama 3 tahun (2014-2016) dengan jumlah perusahaan yang observasi sebanyak 12. Data yang diperoleh dianalisis dengan menggunakan analisis regresi linear berganda. Hasil penelitian menunjukkan bahwa semua hipotesis berpengaruh signifikan berdasarkan uji t dan uji F. Ini berarti bahwa baik secara parsial maupun simultan leverage financial dan kebijakan dividen berpengaruh signifikan terhadap nilai perusahaan pada perusahaan manufaktur di bursa efek Indonesia.
\end{abstract}

Kata Kunci: Leverage Financial, Kebijakan Dividen, Nilai Perusahaan. 
Jurnal Ekonomi Balance Fakultas Ekonomi Dan Bisnis

\section{PENDAHULUAN}

\section{Latar Belakang}

Tujuan dalam pendirian perusahaan adalah untuk memaksimalkan kesejahteraan pemilik perusahaan dengan cara meningkatkan nilai perusahaan. Nilai perusahaan yang sudah go publik di pasar modal tercermin dalam harga saham perusahaan. Untuk memperhitungkan tingkat keuntungan serta risiko tentunya investor membutuhkan suatu informasi akuntansi yang pada umumnya diperoleh dari data fundamental perusahaan yaitu laporan keuangan. Melalui laporan keuangan investor dapat menilai kinerja keuangan perusahaan, khususnya melalui nilai perusahaan. Fenomena penelitian yang terkait nilai perusahaan ((PBVR) pada perusahaan manufaktur sub sektor otomotif dan komponen yang terdaftar di bursa efek Indonesia dari tahun 2014 sampai 2016 terlihat pada tabel berikut:

\section{Tabel 1.}

Fenomena Nilai Perusahaan ((PBVR) pada Perusahaan ManufakturSub Sektor

Otomotif dan Komponen yang Terdaftar di Bursa Efek IndonesiaPeriode

2014-2016

\begin{tabular}{|l|l|}
\hline Tahun & Nilai Perusahaan (PBVR) \\
\hline 2014 & $13,24 \%$ \\
\hline 2015 & $12,50 \%$ \\
\hline 2016 & $29,14 \%$ \\
\hline
\end{tabular}

Sumber:www.bakrieglobal.com/emiten-manufaktur-gemilang, 2018

Fenomena ini dapat dilihat dari nilai perusahaan ((PBVR) pada perusahaan manufaktur sub sektor otomotif dan komponen yang terdaftar di bursa efek Indonesia dari tahun 2014 sampai 2016 mengalami fluktuasi (naik turun). Pada tahun 2014 nilai perusahaan (PBVR) sebesar 13,24\%, sedangkan pada tahun 2015 mengalami penurunan sebesar 12,50\%, namun pada tahun 2016 terjadi peningkatan sebesar 29,14\%, ada indikasi akibat leverage financial dan kebijakan dividen. Terkait dengan fenomena tersebut menggambarkan bahwa nilai perusahaan (PBVR) belum optimal. Menurut Sutrisno (2014:227), nilai perusahaan merupakan nilai pasar yang dapat memberikan kemakmuran pemegang saham secara maksimum apabila harga saham meningkat. 
Jurnal Ekonomi Balance Fakultas Ekonomi Dan Bisnis

Nilai perusahaan dapat mencerminkan nilai aset yang dimiliki perusahaan seperti surat-surat berharga. Saham merupakan salah satu surat berharga yang dikeluarkan oleh perusahaan, tinggi rendahnya harga saham banyak dipengaruhi oleh kondisi emiten. Nilai perusahaan ditunjukkan oleh harga saham perusahaan. Semakin tinggi harga saham perusahaan, maka semakin tinggi pula nilai perusahaan tersebut, sebaliknya semakin rendah harga saham, maka semakin rendah nilai perusahaan tersebut (Fred, 2013:199). Nilai perusahaan dapat diukur dengan Price to Book Value Ratio (PBVR) karena berkaitan dengan pertumbuhan modal sendiri yang membandingkan harga pasar per lembar saham dengan nilai buku per lembar saham (Sutrisno, 2014:227). Faktor lain yang turut menentukan dalam meningkatkan nilai perusahaan adalah leverage financial dan kebijakan dividen.

Leverage financial merupakan kemampuan perusahaan untuk menggunakan aktiva atau dana yang mempunyai beban tetap untuk memperbesar tingkat penghasilan (return) bagi pemilik perusahaan (Agus, 2014:90). Diukur dengan proksi: Laba bersih sesudah bunga dan pajak dengan biaya bunga. Semakin tinggi proporsi hutang maka semakin tinggi nilai perusahaan tersebut atau dengan kata lain semakin tinggi leverage financial perusahaan, semakin besar nilai perusahaan yang akan diperoleh, dan semakin besar pula tingkat risiko yang dihadapi investor nantinya. Kebijakan dividen merupakan keputusan keuangan yang berkaitan dengan penentuan berapa besarnya laba yang tersedia bagi para pemegang saham biasa yang dibagikan kepada para pemegang saham biasa sabagai dividen dan berapa banyak jumlah yang ditahan (Warsono, 2013:271). Diukur dengan proksi: Dividen per lembar saham dengan laba bersih per lembar saham.

Kebijakan dividen merupakan refleksi nilai perusahaan, bahwa perusahaan telah dikelola dengan baik dan berkulitas. Artinya, ada upaya bagi manajemen untuk mengelola nilai perusahaan. Pengelolaan nilai perusahaan yang baik akan memberikan profitabilitas yang tinggi, jika variabel-variabel lain bersifat tetap atau perubahan tidak signifikan. Jadi kaitan antara leverage financial dan kebijakan dividen dengan nilai perusahaan dapat dilihat dari pendapat Sutrisno (2014:227) yang menyatakan bahwa nilai perusahaan merupakan nilai pasar yang dapat memberikan kemakmuran pemegang saham secara maksimum apabila harga saham meningkat. 
Jurnal Ekonomi Balance Fakultas Ekonomi Dan Bisnis

Oleh karena itu dengan leverage financial yang tinggi dan kebijakan dividen yang optimal dapat menggambarkan bagaimana nilai perusahaan yang dicapai. Berdasarkan penelitian terdahulu yang dikemukakan oleh Jalaluddin (2014), mengemukakan leverage financial dan kebijakan dividen tidak berpengaruh signifikan terhadap nilai perusahaan. Penelitian Agusti Restu 2015), disebutkan bahwa leverage financial dan kebijakan dividen tidak berpengaruh signifikan terhadap nilai perusahaan. Berbeda dengan penelitian yang dilakukan oleh Silmian (2014), yang membuktikan leverage financial dan kebijakan dividen memiliki pengaruh positif dan signifikan terhadap nilai perusahaan. Bukti tersebut didukung oleh penelitian Wulandari Nivo (2015), mengemukakan leverage financial dan kebijakan dividen memiliki pengaruh positif dan signifikan terhadap nilai perusahaan.

Ketidaksamaan temuan dalam menjelaskan pengaruh leverage financial dan kebijakan dividen terhadap nilai perusahaan, seperti yang ditunjukkan pada penelitian Silmian (2014) dan Wulandari Nivo (2015) menjadi alasan peneliti untuk memilih variabel leverage financial dan kebijakan dividen dan pengaruhnya terhadap nilai perusahaan karena hal tersebut merupakan hal menarik untuk dikaji lebih lanjut. Alasan memilih tempat penelitian dikarenakan/didasarkan atas fenomena bahwa nilai perusahaan (PBVR) pada perusahaan manufaktur sub sektor otomotif dan komponen yang terdaftar di bursa efek Indonesia dari tahun 2014 sampai 2016 mengalami fluktuasi (naik turun).

\section{LANDASAN TEORI}

\section{Leverage Financial}

Menurut Martojo (2014:295), leverage financial adalah mengacu pada penggunaan asset dan sumber dana perusahaan dimana dalam penggunaan asset atau dana tersebut perusahaan harus mengeluarkan biaya tetap atau beban tetap. Menurut Agus (2014:267), mengukur leverage financial adalah Degree of Financial Leverage (DFL). DFL mengukur laba operasi yang dihasilkan perusahaan jika dibandingkan dengan beban tetap (biaya bunga) yang harus dibayar perusahaan karena penggunaan hutang (leverage financial dengan rumus sebagai berikut:

$$
\mathrm{DFL}=\frac{\text { Laba Bersih Sesudah Bunga dan Pajak (EBIT) }}{\text { EBIT - Biaya bunga }}
$$


Jurnal Ekonomi Balance Fakultas Ekonomi Dan Bisnis

Volume 15 No 2 Tahun 2019

Menurut Zulian (2014:87), mengukur leverage financial adalah Degree of Financial Leverage (DFL). DFL adalah perbandingan antara perubahan laba setelah pajak dengan perubahan laba operasi dengan rumus:

Laba Bersih Sesudah Bunga dan Pajak (EBIT)

$\mathrm{DFL}=$

\section{EBIT - 1}

Perusahaan yang memiliki proporsi hutang dan saham preferen relatif lebih besar dalam struktur modalnya akan memiliki biaya modal tetap yang besar sehingga DFL akan tinggi dan begitu pula sebaliknya

\section{Dividen}

Riyanto, (2013:265), dividen merupakan aliran kas yang dibayarkan kepada para pemegang saham (equty investor). Setiap perusahaan selalu menginginkan adanya pertumbuhan bagi perusahaan tersebut disatu pihak dan juga dapat membayar dividen kepada pemegang saham dipihak lain. Menurut Agus (2014:283), kebijakan dividen adalah keputusan apakah laba yang diperoleh perusahaan akan dibagikan kepada pemegang saham sebagai dividen atau akan ditahan dalam bentuk laba ditahan guna pembiayaan investasi dimasa mendatang. Keputusan untuk membagikan keuntungan yang diperoleh dalam bentuk dividen atau akan ditahan bagi perusahaan adalah ditentukan oleh tingkat keuntungan yang diharapkan atas kesempatan investasi.

\section{Ukuran Kebijakan Dividen}

Menurut Warsono (2013:275), mengukur kebijakan dividen adalah rasio pembayaran dividen (Dividend Payout Ratio/DPR). DPR merupakan rasio hasil perbandingan antara dividen yang diumumkan atau dividen per lembar saham (DPS) dengan laba bersih atau laba per lembar saham dengan rumus:

Dividen yang diumumkan

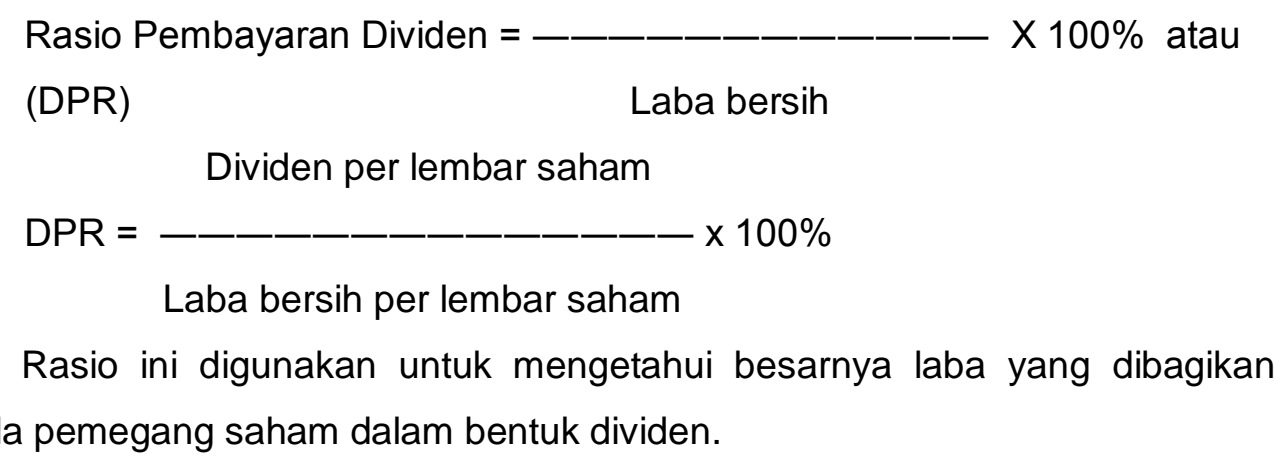


Jurnal Ekonomi Balance Fakultas Ekonomi Dan Bisnis

Volume 15 No 2 Tahun 2019

\section{Faktor-Faktor yang Mempengaruhi Kebijakan Dividen}

Menurut Agus (2014:386), faktor utama yang mempengaruhi kebijakan dividen antara lain:

1. Kebutuhan dana perusahaan

Kebutuhan dana bagi perusahaan dalam kenyataannya merupakan faktor yang harus dipertimbangkan dalam menentukan kebijakan dividen yang akan diambil. Aliran kas perusahaan yang diharapkan pengeluaran modal dimasa datang yang diharapkan, kebutuhan tambahan piutang dan persediaan, pola pengurangan utang dan masih banyak faktor lain yang mempengaruhi posisi kas perusahaan harus dipertimbangkan dalam analisis kebijakan dividen.

2. Likuiditas

Likuditas perusahaan merupakan pertimbangan utama dalam banyak kebijakan dividen, karena dividen bagi perusahaan merupakan kas ke luar, maka semakin besar posisi kas dan likuiditas perusahaan secara keseluruhan akan semakin besar kemampuan perusahaan untuk membayar dividen. Perusahaan yang sedang mengalami pertumbuhan dan profitable akan memerlukan dana yang diperoleh lebih banyak diinvestasikan pada aktiva tetap dan aktiva lancar yang permanen.

3. Kemampuan meminjam

Posisi likuiditas perusahaan dapat diatasi dengan kemampuan perusahaan untuk meminjam dalam jangka pendek. Kemampuan meminjam dalam jangka pendek tersebut akan meningkatkan fleksibilitas likuiditas perusahaan. Perusahaan yang semakin besar dan sudah estabilsh akan memiliki access yang lebih baik di pasar modal. Kemampuan meminjam yang lebih besar, fleksibilitas akan memperbesar kemampuan membayar dividen.

4. Keadaan pemegang saham

Jika perusahaan kepemilikan sahamnya relative tertutup, manajemen biasanya mengetahui dividen yang diharapkan oleh pemegang saham dan dapat bertindak dengan tepat. Jika hampir semua pemegang saham berada dalam golongan pajak tinggi dan lebih suka memperoleh capital gain, maka perusahaan biasa dapat rasio pembayaran dividen (dividend payout ratio) yang rendah. Dengan rasio pembayaran dividen yang rendah tentunya dapat diperkirakan apakah perusahaan dapat menahan laba untuk kepentingan investasi yang profitable. Unuk perusahaan yang jumlah pemegang sahamnya 
Jurnal Ekonomi Balance Fakultas Ekonomi Dan Bisnis

besar hanya dapat menilai dividen yang diharapkan pemegang saham dalam kontek pasar.

5. Stabilitas dividen

Bagi para investor faktor stabilitas dividen akan lebih menarik dari pada rasio pembayaran dividen yang tinggi. Stabiitas dalam arti tetap mmperhatikan tingkat pertumbuhan perusahaan, yang ditunjukkan oleh keefisien yang arah positif. Apabil faktor lain sama, saham yang memberikan dividen yang stabil selama periode tertentu akan mempunyai harga yang lebih tinggi dari pada saham yang membayar dividennya dalam persentase yang tetap terhadap laba.

\section{Nilai Perusahaan}

Menurut Harmono (2014:233), nilai perusahaan adalah kinerja perusahaan yang tercermin oleh harga yang dibentuk oleh permintaan dan penawaran di pasar modal yang merefleksikan penilaian masyarakat terhadap kinerja perusahaan. Bagi perusahaan yang sudah go public, nilai perusahaan akan tercermin dari nilai pasar sahamnya. Semakin tinggi harga saham perusahaan maka semakin tinggi pula nilai perusahaannya.

\section{Ukuran Nilai Perusahaan}

Menurut Sutrisno (2014:227), nilai perusahaan dapat diukur dengan menggunakan sebagai berikut:

\section{Price Earning Ratio (PER)}

Price Eearning Ratio (PER) adalah perbandingan antara harga pasar saham terhadap earning (laba) per lembar saham perusahaan. Investor akan menghitung berapa kali nilai earning yang tercermin dalam harga suatu saham. Adapun rumus untuk menghitung price earning ratio (PER) menurut Teguh (2013:167):

Harga pasar saham

$$
\text { PER }=
$$

$$
\text { Earning/laba per lembar saham (EPS) }
$$

Keterangan:

PER = Price earning ratio

Harga pasar saham = Harga pasar saham penutupan pada akhir tahun 
Jurnal Ekonomi Balance Fakultas Ekonomi Dan Bisnis

EPS = Earning per share, didapat dari laba bersih setelah bunga dan pajak dibagi jumlah saham yang beredar

2. Price to Book Value Ratio (PBVR)

Market to Book Value Ratio (MBVR) atau disebut juga price to book value ratio (PBVR) adalah perbandingan antara harga pasar per lembar saham dengan nlai buku per lembar sahamnya, dimana semakin tingginya rasio ini maka semakin tinggi pula nilai perusahaan. Adapun rumus untuk menghitung price to book value ratio (PBVR) menurut Sutrisno (2014:227):

$$
\text { PBVR = Harga pasar per lembar saham }
$$

\section{Pengaruh Leverage Financial dan Kebijakan Dividen terhadap Nilai Perusahaan}

Menurut Harmono (2014:57), leverage financial atau struktur hutang terjadi karena perusahaan menggunakan sumber dana yang berasal dari modal asing/hutang yang menyebabkan perusahaan menanggung beban tetap. Penggunaan dana yang menyebabkan beban tetap ini, diharapkan memperoleh pendapatan yang lebih besar dibandingkan dengan beban tetap yang harus dibayar oleh perusahaan. Hal ini dilakukan untuk memperoleh nilai perusahaan guna menutupi beban bunga yang harus dibayarkan serta dapat meningkatkan nilai perusahaan per lembar saham.

Selain itu kebijakan dividen menurut Fred (2013:199), kebijakan dividen yang optimal (optimal dividend policy) adalah kebijakan dividen yang menciptakan keseimbangan diantara dividen saat ini dan pertumbuhan dimasa mendatang sehingga memaksimumkan nilai perusahaan. Total pengembalian (return) kepada pemegang saham selama waktu tertentu terdiri dari peningkatan nilai perusahaan ditambah dividen yang diterima. Jika perusahaan menetapkan dividen yang lebih tinggi dari tahun sebelumnya, maka return yang diperoleh investor akan semakin tinggi, sehingga nilai perusahaan meningkat. Hal ini didukung pernyataan empiris dari Silmian (2014) dan Wulandari Nivo (2015), bahwa leverage financial dan kebijakan dividen memiliki pengaruh positif dan signifikan terhadap nilai perusahaan.

\section{Kerangka Konseptual}

Kerangka konseptual ini dimaksudkan untuk menjelaskan, mengungkapkan dan menentukan persepsi-persepsi keterkaitan antara variabel 
Jurnal Ekonomi Balance Fakultas Ekonomi Dan Bisnis

Volume 15 No 2 Tahun 2019

yang akan diteliti yaitu pengaruh leverage financial dan kebijakan dividen terhadap nilai perusahaan. Leverage financial merupakan kemampuan perusahaan untuk menggunakan aktiva atau dana yang mempunyai beban tetap untuk memperbesar tingkat penghasilan (return) bagi pemilik perusahaan, diukur dengan proksi: Laba bersih sebelum bunga dan pajak dengan biaya bunga.

Kebijakan dividen merupakan keputusan keuangan yang berkaitan dengan penentuan berapa besarnya laba yang tersedia bagi para pemegang saham biasa yang dibagikan kepada para pemegang saham biasa sabagai dividen dan berapa banyak jumlah yang ditahan, diukur dengan proksi: Dividen per lembar saham dengan laba bersih per lembar saham. Sedangkan nilai perusahaan merupakan nilai pasar yang dapat memberikan kemakmuran pemegang saham secara maksimum apabila harga saham meningkat, diukur dengan proksi: Harga pasar per lembar saham dengan nilai buku per lembar saham.

Hubungan antara variabel leverage financial dan kebijakan dividen dengan nilai perusahaan telah banyak dilakukan oleh peneliti sebelumnya seperti yang dikemukakan oleh Silmian (2014) dan Wulandari Nivo (2015) yang menunjukkan bahwa leverage financial dan kebijakan dividen berpengaruh signifikan terhadap nilai perusahaan. Berpengaruh secara signifikan artinya dengan adanya leverage financial dan kebijakan dividen yang tinggi dapat meningkatkan nilai perusahaan. Untuk lebih jelasnya berikut dapat digambarkan dalam kerangka konseptual.

\section{Gambar 1. Kerangka Konseptual}

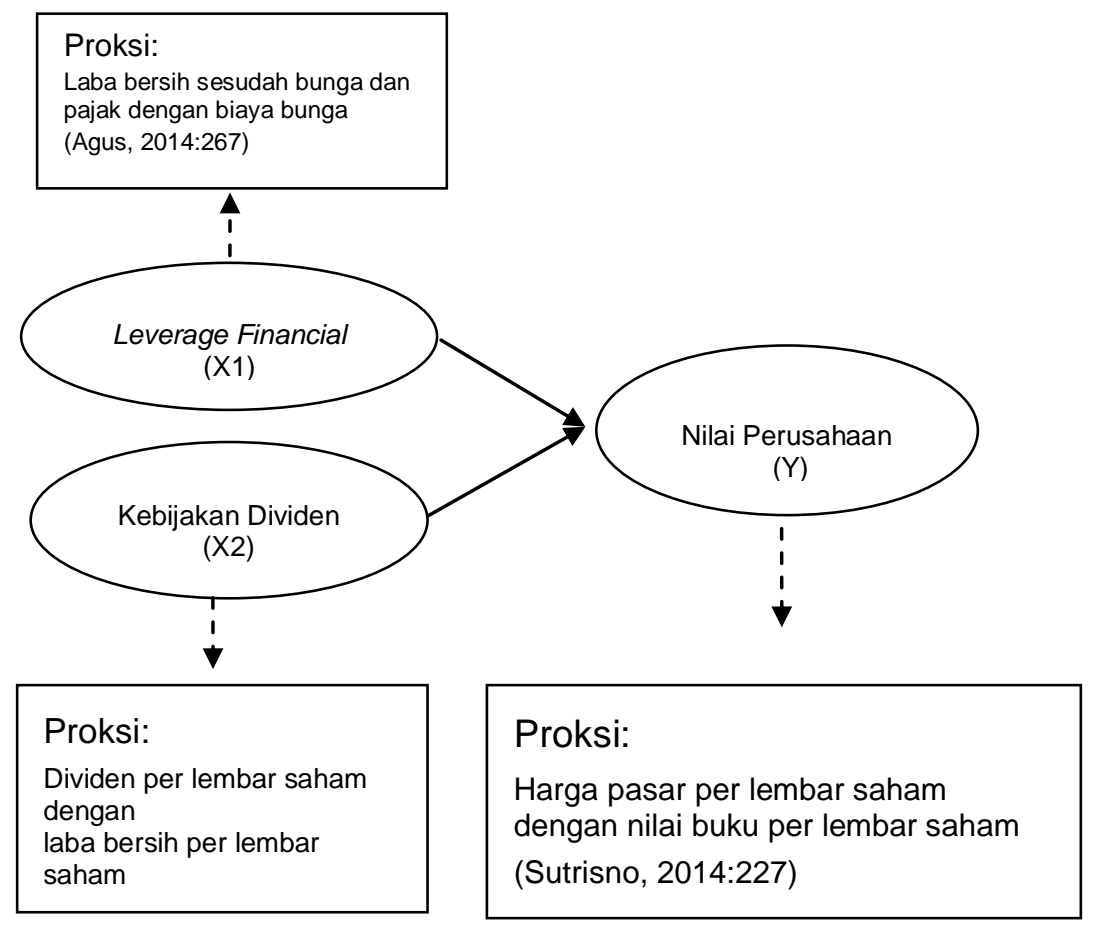


Jurnal Ekonomi Balance Fakultas Ekonomi Dan Bisnis

\section{Hipotesis}

Berdasarkan tinjauan teori, penelitian terdahulu dan kerangka konseptual yang telah disusun diatas, maka dapat diajukan hipotesis yaitu: Leverage financial berpengaruh positif dan signifikan terhadap nilai peusahaan pada perusahaan manufaktur di bursa efek Indonesia. Kebijakan dividen berpengaruh positif dan signifikan terhadap nilai peusahaan pada perusahaan manufaktur di bursa efek Indonesia. Leverage financial dan kebijakan dividen secara simultan berpengaruh positif dan signifikan terhadap nilai peusahaan pada perusahaan manufaktur di bursa efek Indonesia.

\section{METODE PENELITIAN}

\section{Populasi dan Sampel}

Populasi dalam penelitian ini adalah perusahaan manufaktur sub sektor otomotif dan komponen yang terdaftar di bursa efek Indonesia selama periode 2014-2016 sejumlah 15 perusahaan. Dalam penentuan sampel pada penelitian ini menggunakan teknik purposive sampling dengan kriteria:

1. Perusahaan yang masuk dalam sampel penelitian adalah perusahaan-perusahaan manufaktur sub sektor otomotif dan komponen yang terdaftar (listing) di bursa efek Indonesia.

2. Perusahaan tercatat di bursa efek Indonesia selama jangka waktu pengamatan.

3. Perusahaan mempunyai laporan keuangan yang lengkap.

Untuk menentukan besarnya sampel dari kriteria yang ditetapkan dalam penelitian ini, disajikan dalam tabel 2 berikut:

Tabel 2. Distribusi Sampel

\begin{tabular}{|l|l|}
\hline Kriteria & $\begin{array}{l}\text { Jumlah } \\
\text { Perusahaan }\end{array}$ \\
\hline $\begin{array}{l}\text { Jumlah perusahaan industri otomotif yang terdaftar berturut- } \\
\text { turut di BEl dalam kurun waktu 2014-2016 }\end{array}$ & $\mathbf{1 5}$ \\
\hline $\begin{array}{l}\text { Perusahaan industri otomotif yang tidak memiliki } \\
\text { kelengkapan data yang dibutuhkan selama periode 2014- } \\
\text { 2016. }\end{array}$ & $\mathbf{1 5}$ \\
\hline Jumlah perusahaan yang memenuhi kriteria & $\mathbf{1 2}$ \\
\hline
\end{tabular}

Sumber: Indonesian Stock Exchange (IDX, 2014-2016 
Jurnal Ekonomi Balance Fakultas Ekonomi Dan Bisnis

Volume 15 No 2 Tahun 2019

Berdasarkan kriteria yang ditetapkan di atas, maka jumlah perusahaan yang memenuhi kriteria sebanyak 12 perusahaan. Berikut ini disajikan nama perusahaan dan kode perusahaan yang memenuhi kriteria yakni pada tabel 3 berikut:

Tabel 3 Perusahaan yang Memenuhi Kriteria Sebagai Sampel

\begin{tabular}{|c|c|c|}
\hline No & Nama Perusahaan & Kode Perusahaan \\
\hline $\mathbf{1 .}$ & PT. Astra Internasional, Tbk. & ASII \\
\hline $\mathbf{2}$ & PT. Astra Otoparts, Tbk. & AUTO \\
\hline $\mathbf{3}$ & PT. Indo Korsa, Tbk & BRAM \\
\hline $\mathbf{4}$ & PT. Goodyear Indonesia, Tbk & GDYR \\
\hline $\mathbf{5}$ & PT. Gaja Tunggal, Tbk & GJTL \\
\hline $\mathbf{6}$ & PT. Indomobil Sukses International, Tbk. & IMAS \\
\hline $\mathbf{7}$ & PT. Indospring, Tbk. & INDS \\
\hline $\mathbf{8}$ & PT. Multi Prima Sejahtera, Tbk. & LPIN \\
\hline $\mathbf{9}$ & PT. Multistrada Arah Sarana, Tbk & MASA \\
\hline $\mathbf{1 0}$ & PT. Nipress, Tbk. & NIPS \\
\hline $\mathbf{1 1}$ & PT. Prima Alloy Steel Universal, Tbk & PRAS \\
\hline $\mathbf{1 2}$ & PT. Selamat Sempurna, Tbk & SMSM \\
\hline
\end{tabular}

Sumber: Indonesian Stock Exchange (IDX, 2014-2016)

Periode pengamatan dalam penelitian ini adalah 3 tahun dengan jumlah perusahaan yang observasi sebanyak 12 , maka jumlah sampel sebanyak $12 \times 3$ tahun $=36$ sampel.

\section{Metode Pengumpulan Data}

Jenis data yang digunakan dalam penelitian ini adalah data sekunder berupa laporan keuangan perusahaan yang diperoleh dari laporan tahunan perusahaan sub sektor otomotif dan komponen yang go publik di BEI periode 2014-2016. Sumber data yang digunakan dalam penelitian ini adalah data sekunder, yaitu data yang diperoleh dari ICMD (Indonesian Capital Market Directory) atau data dari IDX (Indonesian Stock Exchange). Teknik yang digunakan untuk mengumpulkan data dalam penelitian ini adalah metode dokumentasi, yaitu dengan cara mengumpulkan, mencatat dan mengkaji data sekunder yang berupa laporan keuangan perusahaan sub sektor otomotif dan komponen yang dipublikasikan oleh BEI melalui IDX (Indonesian Stock Exchange) serta dari berbagai buku pendukung dan sumber-sumber lainnya 
Jurnal Ekonomi Balance Fakultas Ekonomi Dan Bisnis

Volume 15 No 2 Tahun 2019

yang berhubungan dengan leverage financial, kebijakan dividen dan nilai perusahaan.

\section{Metode Analisis}

Metode analisis data yang digunakan dalam penelitian ini adalah analisis regresi linear berganda dimana analisis ini digunakan untuk menguji dan menganalisis pengaruh leverage financial dan kebijakan dividen terhadap nilai perusahaan. Menurut Sugiyono (2017:215) dengan rumus:

$$
Y=a+b 1 X 1+b 2 X 2+e
$$

Keterangan:

$$
\begin{array}{ll}
\mathrm{Y} & =\text { Nilai perusahaan } \\
\mathrm{a} & =\text { Konstanta } \\
\mathrm{b} 1-\mathrm{b} 2 & =\text { Koefisien regresi (parameter) } \\
\mathrm{X} 1 & =\text { Leverage financial } \\
\mathrm{X} 2 & =\text { Kebijakan dividen } \\
\mathrm{e} & =\text { Standar error (variabel pengganggu) }
\end{array}
$$

\section{Uji Hipotesis}

\section{Uji Parsial (Uji - t)}

Menurut Sugiyono (2017:251) uji - t (parsial), digunakan untuk menguji masing-masing variabel leverage financial (X1) dan Kebijakan dividen (X2) berpengaruh terhadap Nilai perusahaan $(Y)$.

Hipotesis 1

$\mathrm{H} 01: \beta 1=0$, Leverage financial tidak berpengaruh terhadap nilai perusahaan.

Ha1: $\beta 1 \neq 0$, Leverage financial berpengaruh positif dan signifikan terhadap terhadap nilai perusahaan.

Kriteria pengambilan keputusan:

1. H01 diterima jika nilai signifikan $>$ dari taraf signifikan dan nilai thitung

$<$ ttabel pada

$$
\alpha=5 \%(0,05) \text {. }
$$

2. Ha1 diterima jika nilai signifikan < dari taraf signifikan dan nilai thitung $>$ ttabel pada

$$
\alpha=5 \%(0,05) \text {. }
$$

Hipotesis 2

H02 : $\beta 2=0$, Kebijakan dividen tidak berpengaruh terhadap nilai perusahaan. 
Jurnal Ekonomi Balance Fakultas Ekonomi Dan Bisnis

Ha2 : $\beta 2 \neq 0$, Kebijakan dividen berpengaruh positif dan signifikan terhadap nilai perusahaan.

Kriteria pengambilan keputusan:

1. H02 diterima jika nilai signifikan $>$ dari taraf signifikan dan nilai thitung $<$ ttabel pada $\alpha=5 \%(0,05)$.

2. Ha2 diterima jika nilai signifikan < dari taraf signifikan dan nilai thitung $>$ ttabel pada

$$
\alpha=5 \%(0,05) \text {. }
$$

\section{Uji Simultan (Uji F)}

Menurut Sugiyono (2017:274) uji simultan atau uji F, digunakan untuk menguji variabel leverage financial (X1) dan kebijakan dividen (X2) secara simultan/bersama-sama berpengaruh terhadap nilai perusahaan $(Y)$.

Hipotesis 3

$\mathrm{H} 03: \beta 3=0$, Leverage financial dan kebijakan dividen tidak berpengaruh terhadap nilai perusahaan.

Ha3 : $\beta 3 \neq 0$, Leverage financial dan kebijakan dividen berpengaruh positif dan signifikan terhadap nilai perusahaan.

Kriteria pengambilan keputusan:

1. H03 diterima jika nilai signifikan > dari taraf signifikan dan nilai Fhitung < Ftabel pada

$$
\alpha=5 \%(0,05) \text {. }
$$

2. Ha3 diterima jika nilai signifikan < dari taraf signifikan dan nilai Fhitung $>$ Ftabel pada

$$
\alpha=5 \%(0,05) \text {. }
$$

\section{Uji Koefisien Determinasi $\left(\mathbf{R}^{2}\right)$}

Menurut Ghozali (2014:106) uji koefisien determinasi $\left(R^{2}\right)$, digunakan untuk melihat besarnya pengaruh leverage financial dan kebijakan dividen sebagai variabel independen terhadap nilai perusahaan sebagai variabel devenden. Nilai $\mathrm{R}^{2}$ ini terletak antara 0 (nol) dan 1 (satu). Bila nilai $\mathrm{R}^{2}$ mendekati 0 , berarti sedikit sekali variasi variabel dependen yang diterangkan oleh variabel independen. Jika nilai $\mathrm{R}^{2}$ bergerak mendekati 1 (satu) berarti semakin besar variasi variabel dependen yang dapat diterangkan oleh variabel independen jika ternyata dalam perhitungan nilai $\mathrm{R}^{2}$ sama dengan 0 maka ini menunjukkan 
Jurnal Ekonomi Balance Fakultas Ekonomi Dan Bisnis

Volume 15 No 2 Tahun 2019

bahwa variabel dependen tidak bisa dijelaskan oleh variabel independen dengan formulasi: $R^{2}=(R)^{2} \times 100 \%$.

\section{HASIL DAN PEMBAHASAN}

\section{Analisis Regresi Linear Berganda}

Penelitian ini menggunakan model analisis regresi linear berganda untuk menguji dan menganalisis pengaruh leverage financial dan kebijakan dividen terhadap nilai peusahaan pada perusahaan manufaktur di bursa efek Indonesia. Melalui perhitungan dengan menggunakan SPSS (Statistik Product and Standart Solution) versi 20 sebagai berikut:

Tabel 4. Hasil Pengujian Regresi Linear Berganda Coefficients $^{a}$

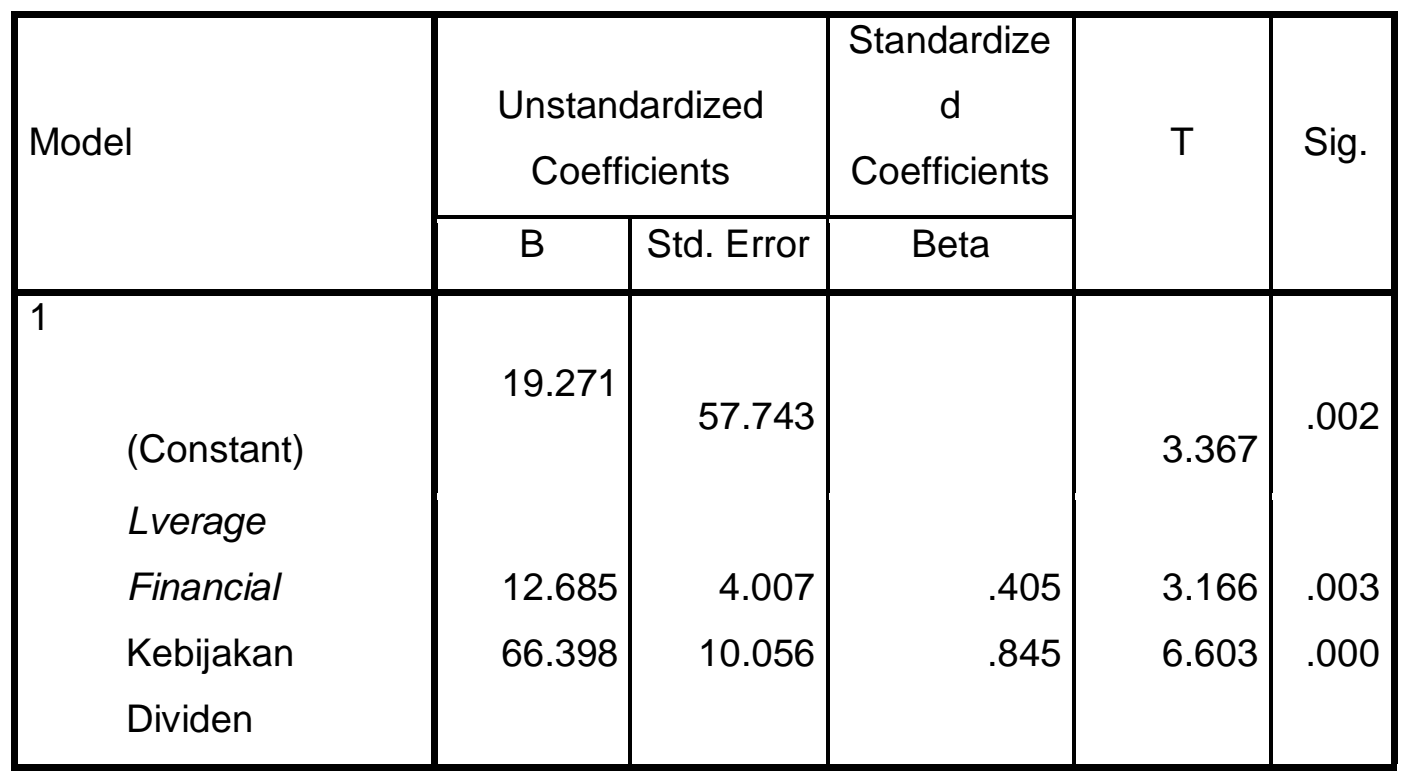

a. Dependent Variable: Nilai Perusahaan

Sumber:Output SPSS V23, 2018

Berdasarkan tabel 4 di atas, diperoleh persamaan regresi linear berganda sebagai berikut:

$$
Y=a+b 1 X 1+b 2 X 2
$$

Dimana:

$Y=19,271+12,685 X 1+66,398 X 2$

Model tersebut dapat diinterpretasikan sebagai berikut:

1. $\mathrm{a}=19,271$ yang merupakan nilai konstanta artinya bahwa tanpa adanya leverage financial 
Jurnal Ekonomi Balance Fakultas Ekonomi Dan Bisnis

Volume 15 No 2 Tahun 2019

dan kebijakan dividen maka nilai perusahaan sebesar 19,271\%.

2. $b_{1}=12,685$, artinya penambahan frekuensi leverage financial sebesar satu satuan akan mempengaruhi peningkatan nilai perusahaan sebesar $12,685 \%$.

3. $b_{2}=66,398$, artinya penambahan frekuensi kebijakan dividen sebesar datu satuan akan mempengaruhi peningkatan nilai perusahaan sebesar $66,398 \%$.

Hasil analisis regresi linear berganda memberikan gambaran bahwa variabel independen memiliki hubungan yang positif terhadap variabel dependennya yaitu tingkat pengaruh yang ditunjukkan dengan nilai koefisien leverage financial dan kebijakan dividen yang berhubungan positif terhadap nilai perusahaan.

\section{Hasil Pengujian Hipotesis}

\section{Hasil Uji Parsial (Uji t)}

Hasil uji statistik t pada dasarkan menunjukkan seberapa jauh pengaruh satu variabel bebas (independen) secara parsial atau individual dalam mempengaruhi variabel tidak bebas (dependen). Tabel berikut menggambarkan hasil uji statistik t.

Tabel 5. Hasil Uji Parsial (Uji t)

Coefficients $^{\mathrm{a}}$

\begin{tabular}{|c|c|c|}
\hline Model & $\mathrm{T}$ & Sig. \\
\hline $\begin{array}{l}\text { (Constant) } \\
\text { Lverage Financial } \\
\text { Kebiiakan Dividen }\end{array}$ & $\begin{array}{l}3.367 \\
3.166 \\
6.603\end{array}$ & $\begin{array}{l}.002 \\
.003 \\
.000\end{array}$ \\
\hline
\end{tabular}

a.Dependent Variable: Nilai Perusahaan

mber:Output SPSS V23, 2018

1. Hasil pengujian hipotesis pertama $(\mathrm{H} 1)$ dengan uji pengaruh leverage financial terhadap nilai perusahaan. Berdasarkan tabel 5 variabel leverage financial memiliki nilai thitung 3,166 dengan nilai signifikansi 0,003 , tingkat signifikan 5\% atau 0,05 dan derajat bebas (df) $=\mathrm{n}-\mathrm{k}-1$ (pada penelitian ini $\mathrm{df}$ $=36-2-1=33$ ). Hal ini menunjukkan bahwa nilai signifikansi tersebut lebih 
Jurnal Ekonomi Balance Fakultas Ekonomi Dan Bisnis

Volume 15 No 2 Tahun 2019

kecil dari taraf signifikansi $5 \%$ atau $0,05 \quad(0,003<0,05$ dan nilai thitung lebih besar dari nilai ttabel $(3,166>1,692)$ maka H01 ditolak dan Ha1 diterima. Artinya leverage financial berpengaruh positif dan signifikan terhadap nilai perusahaan.

2. Hasil pengujian hipotesis kedua $(\mathrm{H} 2)$ dengan uji pengaruh kebijakan dividen terhadap nilai Perusahaan. Berdasarkan tabel 5 variabel kebijakan deviden memiliki nilai thitung 6,603 dengan nilai signifikansi 0,000 , tingkat signifikan $5 \%$ atau 0,05 dan derajat bebas $(\mathrm{df})=\mathrm{n}-\mathrm{k}-1$ (pada penelitian ini $\mathrm{df}=36-2-1$ = 33). Hal ini menunjukkan bahwa nilai signifikansi tersebut lebih kecil dari taraf signifikansi 5\% atau 0,05 $(0,000<0,05$ dan nilai thitung lebih besar dari nilai ttabel $(6,603>1,692)$ maka $\mathrm{H} 02$ ditolak dan Ha2 diterima. Artinya kebijakan deviden berpengaruh positif dan signifikan terhadap nilai perusahaan.

\section{Hasil Uji Simultan (Uji F)}

Hasil uji simultan atau uji Fmerupakan uji secara simultan/ bersama-sama untuk menguji siginifikan pengaruh variabel leverage financial dan kebijakan dividen terhadap nilai perusahaan pada perusahaan manufaktur sub sektor otomotif dan komponen yang terdaftar di bursa efek Indonesia. Tabel berikut menggambarkan hasil uji statistik F.

Tabel 6. Hasil Uji Simultan (Uji F)

\begin{tabular}{|l|l|r|r|r|r|r|}
\multicolumn{7}{|l|}{ ANOVA $^{\text {a }}$} \\
\hline \multicolumn{2}{|l|}{ Model } & $\begin{array}{c}\text { Sum of } \\
\text { Squares }\end{array}$ & Df & $\begin{array}{c}\text { Mean } \\
\text { Square }\end{array}$ & F & Sig. \\
\hline 1 & Regression & 488.623 & 2 & 244.312 & 9.46 & $.000^{\text {b }}$ \\
\hline & Residual & 1161.692 & 33 & 35.203 & & \\
\hline & Total & 1650.315 & 35 & & & \\
\hline
\end{tabular}

a. Dependent Variable: Nilai Perusahaan

b. Predictors: (Constant), Leverage Financial dan Kebijakan Dividen

Sumber:Output SPSS V23, 2018 
Jurnal Ekonomi Balance Fakultas Ekonomi Dan Bisnis

Hasil pengujian hipotesis ketiga $(\mathrm{H} 3)$ dengan uji pengaruh leverage financial dan kebijakan dividen terhadap nilai perusahaan. Berdasarkan tabel 6 di atas, hasil pengujian $F$ yang dilakukan diperoleh Fhitung sebesar 9,464, sedangkan Ftabel sebesar 3,280, dengan derajat bebas (df) $=n-k-1$ (pada penelitian ini $\mathrm{df}=36-2-1=33$ ), tingkat signifikan $5 \%$ atau 0,05 . Maka dapat disimpulkan Fhitung sebesar 9,464 > Ftabel 3,280 dan signifikan yang dilihat dari signifikansi $(0,000)$ lebih kecil dari taraf signifikansi yang disyaratkan sebesar $5 \%$ $(0,05)$, arti secara statistik bahwa hipotesis alternatif tiga ( $\mathrm{Ha} 3)$ diterima, hipotesis nol tiga ( $\mathrm{H} 03)$ ditolak. Artinya leverage financial dan kebijakan dividen secara simultan berpengaruh positif dan signifikan terhadap nilai perusahaan.

\section{Hasil Uji Koefisien Determinasi $\left(\mathbf{R}^{2}\right)$}

Koefisien determinasi $\left(R^{2}\right)$ menunjukkan besarnya besarnya pengaruh leverage financial dan kebijakan dividen sebagai variabel independen terhadap nilai perusahaan sebagai variabel devenden. Nilai koefisien sebesar 1 menunjukkan bahwa variabel independen yang digunakan $100 \%$ tepat (sempurna) dalam menjelaskan variasi yang terjadi pada variabel dependen. Berdasarkan hasil pengolahan data maka diperoleh nilai koefisien determinasi $\left(R^{2}\right)$ sebagai berikut:

Tabel 7.

Hasil Uji Koefisien Determinasi $\left(\mathbf{R}^{2}\right)$

Model Summary ${ }^{b}$

\begin{tabular}{|l|r|r|r|r|}
\hline Model & $\mathrm{R}$ & R Square & \multicolumn{1}{|c|}{$\begin{array}{c}\text { Adjusted R } \\
\text { Square }\end{array}$} & $\begin{array}{c}\text { Std. Error Of } \\
\text { The Estimate }\end{array}$ \\
\hline 1 & $.755^{\mathrm{a}}$ & .570 & .543 & 183955.093 \\
\hline
\end{tabular}

a. Predictors: (constant), Leverage Financial dan Kebijakan Dividen

b. Dependent Variable: Nilai Perusahaan

Sumber:Output SPSS V23, 2018

Berdasarkan tabel 7 menunjukkan bahwa nilai $R$ Square $\left(\mathrm{R}^{2}\right)$ yang digunakan untuk menghitung pengaruh variabel independen (X1 dan X2) terhadap variabel dependen $(Y)$ sebesar 0,570 atau 57,0\%. Hal ini berarti bahwa sebesar $57,0 \%$ nilai perusahaan dipengaruhi oleh leverage financial dan kebijakan dividen. Adapun 43,0\% (100\% - 57,0\%) dipengaruhi oleh faktor-faktor lainnya yang tidak diteliti. 
Jurnal Ekonomi Balance Fakultas Ekonomi Dan Bisnis

\section{PEMBAHASAN}

\section{Pengaruh Leverage Financial terhadap Nilai Perusahaan (H1)}

Hasil penelitia ini menunjukkan bahwa leverage financial berpengaruh positif dan terhadap nilai peusahaan. Positif dan signifikan terlihat dari nilai thitung sebesar 3,166 > ttabel sebesar 1,692 dan tingkat signifikansinya $(0,003)$ lebih kecil dari taraf signifikansi yang disyaratkan sebesar $5 \%(0,05)$. Hal ini membuktikan hipotesis penelitian bahwa leverage financial berpengaruh positif dan signifikan terhadap nilai perusahaan, artinya dengan adanya leverage financial yang tinggi dapat meningkatkan nilai perusahaan. Hasil penelitian ini sejalan dengan teori Sutrisno (2014:227) menyatakan bahwa nilai perusahaan merupakan nilai pasar yang dapat memberikan kemakmuran pemegang saham secara maksimum apabila harga saham meningkat. Nilai perusahaan dapat mencerminkan nilai aset yang dimiliki perusahaan seperti surat-surat berharga. Saham merupakan salah satu surat berharga yang dikeluarkan oleh perusahaan, tinggi rendahnya harga saham banyak dipengaruhi oleh kondisi emiten. Nilai perusahaan ditunjukkan oleh harga saham perusahaan. Semakin tinggi harga saham perusahaan, maka semakin tinggi pula nilai perusahaan tersebut, sebaliknya semakin rendah harga saham, maka semakin rendah nilai perusahaan tersebut. Tinggi rendahnya nilai perusahaan dipengaruhi oleh tinggi rendahnya beberapa faktor seperti leverage financial.

Penelitian ini juga didukung oleh Silmian (2014), yang menemukan bahwa leverage financial dan kebijakan dividen berpengaruh positif dan signifikan terhadap nilai perusahaan. Hal ini menunjukkan bahwa semakin tinggi leverage financial maka dapat meningkatkan nilai perusahaan pada perusahaan manufaktur sub sektor otomotif dan komponen yang terdaftar di bursa efek Indonesia.

\section{Pengaruh Kebijakan Dividen terhadap Nilai Perusahaan (H2)}

Hasil penelitian ini menunjukkan bahwa kebijakan dividen berpengaruh positif dan signifikan terhadap nilai peusahaan. Positif dan signifikan terlihat dari nilai thitung sebesar 6,603 > ttabel sebesar 1,692 dan tingkat signifikansinya $(0,000)$ lebih kecil dari taraf signifikansi yang disyaratkan sebesar $5 \%(0,05)$. Hal ini membuktikan hipotesis penelitian bahwa kebijakan dividen berpengaruh positif dan signifikan terhadap nilai perusahaan, artinya dengan adanya kebijakan dividen yang tinggi dapat meningkatkan nilai perusahaan. 
Jurnal Ekonomi Balance Fakultas Ekonomi Dan Bisnis

Volume 15 No 2 Tahun 2019

Hasil penelitian ini sejalan dengan teori Sutrisno (2014:227) menyatakan bahwa nilai perusahaan merupakan nilai pasar yang dapat memberikan kemakmuran pemegang saham secara maksimum apabila harga saham meningkat. Nilai perusahaan dapat mencerminkan nilai aset yang dimiliki perusahaan seperti surat-surat berharga. Saham merupakan salah satu surat berharga yang dikeluarkan oleh perusahaan, tinggi rendahnya harga saham banyak dipengaruhi oleh kondisi emiten. Nilai perusahaan ditunjukkan oleh harga saham perusahaan. Semakin tinggi harga saham perusahaan, maka semakin tinggi pula nilai perusahaan tersebut, sebaliknya semakin rendah harga saham, maka semakin rendah nilai perusahaan tersebut. Tinggi rendahnya nilai perusahaan dipengaruhi oleh tinggi rendahnya beberapa faktor seperti kebijakan dividen.

Penelitian ini juga didukung oleh Wulandari Nivo (2015), yang menemukan bahwa leverage financial dan kebijakan dividen berpengaruh positif dan signifikan terhadap nilai perusahaan. Hal ini menunjukkan bahwa semakin tinggi kebijakan dividen maka dapat meningkatkan nilai perusahaan pada perusahaan manufaktur sub sektor otomotif dan komponen yang terdaftar di bursa efek Indonesia.

\section{Pengaruh Leverage Financial dan Kebijakan Dividen Secara Simultan terhadap Nilai \\ Perusahaan (H3)}

Hasil penelitian ini menunjukkan bahwa leverage financial dan kebijakan dividen secara simultan berpengaruh positif dan signifikan terhadap nilai perusahaan. Positif dan signifikan terlihat dari nilai Fhitung sebesar 3,166 > Ftabel sebesar 3,280 dan tingkat signifikansinya $(0,000)$ lebih kecil dari taraf signifikansi yang disyaratkan sebesar $5 \%(0,05)$. Hal ini membuktikan hipotesis penelitian bahwa leverage financial dan kebijakan dividen secara simultan berpengaruh positif dan signifikan terhadap nilai perusahaan, artinya dengan adanya leverage financial dan kebijakan dividen yang tinggi dapat meningkatkan nilai perusahaan.

Pada koefisien determinasi $\left(\mathrm{R}^{2}\right)$ yang menunjukkan nilai $R$ Square sebesar 0,570. Hal ini menunjukkan bahwa pengaruh leverage financial dan kebijakan dividen terhadap nilai perusahaan adalah sebesar 57,0\%. Hasil penelitian ini sejalan dengan teori Sutrisno (2014:227) menyatakan bahwa nilai perusahaan merupakan nilai pasar yang dapat memberikan kemakmuran 
Jurnal Ekonomi Balance Fakultas Ekonomi Dan Bisnis

pemegang saham secara maksimum apabila harga saham meningkat. Nilai perusahaan dapat mencerminkan nilai aset yang dimiliki perusahaan seperti surat-surat berharga. Saham merupakan salah satu surat berharga yang dikeluarkan oleh perusahaan, tinggi rendahnya harga saham banyak dipengaruhi oleh kondisi emiten. Nilai perusahaan ditunjukkan oleh harga saham perusahaan. Semakin tinggi harga saham perusahaan, maka semakin tinggi pula nilai perusahaan tersebut, sebaliknya semakin rendah harga saham, maka semakin rendah nilai perusahaan tersebut. Tinggi rendahnya nilai perusahaan dipengaruhi oleh tinggi rendahnya beberapa faktor seperti leverage financial dan kebijakan dividen.

Penelitian ini juga didukung oleh Silmian (2014), yang menemukan bahwa leverage financial dan kebijakan dividen berpengaruh positif dan signifikan terhadap nilai perusahaan. Hal ini menunjukkan bahwa semakin tinggi leverage financial dan kebijakan dividen maka dapat meningkatkan nilai perusahaan pada perusahaan manufaktur sub sektor otomotif dan komponen yang terdaftar di bursa efek Indonesia.

\section{PENUTUP}

\section{Simpulan}

Berdasarkan hasil pengujian hipotesis dan mengacu pada perumusan serta tujuan dari penelitian ini, maka dapat ditarik kesimpulan bahwa:

1. Leverage financial berpengaruh positif dan signifikan terhadap nilai peusahaan pada perusahaan manufaktur di bursa efek Indonesia, artinya ketika leverage financial meningkat maka nilai peusahaan akan meningkat.

2. Kebijakan dividen berpengaruh positif dan signifikan terhadap nilai peusahaan pada perusahaan manufaktur di bursa efek Indonesia, artinya ketika kebijakan dividen meningkat maka nilai peusahaan akan meningkat.

\section{Saran}

Berdasarkan kesimpulan yang telah dikemukakan, ada beberapa saran yang dapat dipertimbangkan oleh perusahaan yaitu dari hasil penelitian ini terlihat bahwa, leverage financial dan kebijakan dividen berpengaruh positif dan signifikan terhadap nilai peusahaan, maka diharapkan pihak pimpinan perusahaan terus meningkatkan nilai peusahaan pada perusahaan manufaktur di bursa efek Indonesia. 
Jurnal Ekonomi Balance Fakultas Ekonomi Dan Bisnis

\section{DAFTAR PUSTAKA}

Anoraga, Pandji. (2013). Pengantar Pasar Modal. Jakarta : Rineka Cipta.

Bambang, Riyanto. (2013). Dasar-Dasar Pembelanjaan Perusahaan. Yogyakarta: : Penerbit YP. Gajah Mada.

Baridwan, Zaki. (2013). Analisa Laporan Keuangan. Edisi II. Yogyakarta : Penerbit BPFE.

Darmadji, Tjiptono. (2013). Pasar Modal di Indonesia. Jakarta : Salemba Empat.

Ghozali, Imam. (2014). Aplikasi Analisis Multivariat dengan Program SPSS. Semarang : Badan Penerbit Universitas Diponegoro.

Harjito, Martojo. (2014). Manajemen Keuangan. Edisi Kedua. Cetakan Kedua. Yogyakarta :Penerbit Ekonisia Kampus Fakultas Ekonomi Universitas Indonesia.

Harmono. (2014). Manajemen Keuangan Berbasis Balanced Scorecard Pendekatan Teori, Kasus dan Riset Bisnis. Jakarta : Bumi Aksara.

http://www.bakrieglobal.com/news/2914/emiten/manufaktu gemilang. (tanggal akses: 4 januari 2017).

Istijanto. (2013). Riset Sumber Daya Manusia. Jakarta : Cetakan Ke Empat. PT. Gramedia Pustaka Utama.

Jalaluddin. (2014). Pengaruh Leverage Financial dan Kebijakan Dividen terhadap Nilai Perusahaan pada Perusahaan Plastik dan Kemasan di Bursa Efek Indonesia . Fe Unsil Universitas Siliwangi : Jurnal Akuntansi. 3 (1) $77-113$.

Lukanul, Hakim. (2014). Pasar Modal. Bandung : Alphabet. Marom,Chairul. (2014). Pedoman Penyajian Laporan Keuangan, Penerbit Grasindo, Jakarta. 
Jurnal Ekonomi Balance Fakultas Ekonomi Dan Bisnis

Munawir S. (2013). Analisa Laporan Keuangan. Jakarta : Edisi Revisi Liberty. Cetakan Keenam. Ghalia Indonesia.

Nivo, Wulandari. (2015). Pengaruh Leverage Financial dan Kebijakan Dividen terhadap Nilai Perusahaan (Studi pada Perusahaan Makanan dan Minuman di Bursa Efek Indonesia : Jurnal Riset Akuntansi, Manajemen dan Ekonomi.2 (1).

Pudjo, Teguh. (2013). Aplikasi Akuntansi Manajemen Dalam Praktek Perbankan. Jakarta : PT Gunung Agung.

Restu, Agusti. (2015). Pengaruh Leverage Financial dan Kebijakan Dividen terhadap Nilai Perusahaan pada Perusahaan Manufaktur Sektor Tekstil dan Garmen di Bursa Efek Indonesia . Fe Unsil Universitas Siliwangi : Jurnal Riset Akuntansi, Manajemen dan Ekonomi.2 (1).

Sartono, Agus. (2014). Manajemen Keuangan, Teori dan Aplikasi. Yogyakarta : Edisi Keempat, Cetakan Pertama, Penerbit BPFE.

Siahaan, Hinca. (2014). Panduan Berinvestasi Saham. Jakarta : Edisi I1. Cetakan Ketiga. PT. Elex Media Komputindo.

Silmian.(2014).Pengaruh Leverage Financial dan Kebijakan Dividen terhadap Nilai Perusahaan pada Perusahaan Manufaktur Yang Terdafar di Bursa Efek Indonesia : Jurnal Riset Manajemen Sains Indonesia.3 (1).

Sugiyono. (2017). Statistik Untuk Penelitian, Bandung : Cetakan Ke Tujuh, Alfabeta.

Sunariyah. (2013). Pengantar Pengetahuan Pasar Modal. Yogyakarta : Edisi 5. Sekolah Tingg IImu Manajemen YKPN.

Sutrisno. (2014). Manajemen Keuangan : Teori, Konsep dan Aplikasi. Yogyakarta : Penerbit Ekonesia. 
Jurnal Ekonomi Balance Fakultas Ekonomi Dan Bisnis

Volume 15 No 2 Tahun 2019

Undang-Undang Republik Indonesia Nomor 8 Tahun, 1995. tentang Pasar Modal. Jakarta.

Warsono. (2013). Manajemen Keuangan Perusahaan. Malang :Penerbit Bayumedia Publishing.

Weston, Fred J. (2013). Dasar-Dasar Manajemen Keuangan Jilid 2. Jakarta Erlangga.

Yamit, Zulian. (2014). Manajemen Keuangan. Jakarta : Edisi Kedua, Cetakan Keempat, Penerbit Ekonisia. 